Marquette University

e-Publications@Marquette

$1-1-2005$

\title{
Religious Affiliation and Individual International- Policy Preferences in the United States
}

Joseph P. Daniels

Marquette University, joseph.daniels@marquette.edu

Accepted version. International Interactions, Vol. 31, No. 4 (October 2005): 273-301. DOI. (C) 2005 Taylor \& Francis (Routledge). Used with permission. 


\title{
Religious Affiliation and Individual International-Policy Preferences in the United States
}

\author{
Joseph P. Daniels \\ Department of Economics, Marquette University \\ Milwaukee, WI
}

\begin{abstract}
Empirical examination of individual-level survey data on national identity, in general, reveals a significant relationship between religious affiliation and an individual's international-policy preferences and that this relationship varies across Protestant denominations. Specifically, we test attitudes toward import and immigration policies, the role of international institutions, and unilateral policy actions. The empirical results indicate that individuals affiliated with conservative Protestant denominations are more likely to support positions on international issues that can be regarded as consistent with the anti-globalist right. We also find evidence of a reinforcing regional effect among conservatives in the south, and differences in the preferences of Baptist and non-Baptist African Americans.
\end{abstract}

Keywords: Religion, international policy preferences, survey data, trade policy, immigration policy

Since Max Weber's (1958) study of the Protestant ethic, scholars from a wide variety of academic disciplines have debated the effects of religion on a nation's economic performance. Recently there has been a rekindling of interest among economists on the role of religion in shaping individual traits, attitudes toward economic policies, and the resulting effects on potential economic prosperity. Iannaccone 
$(1998$, p. 1465), in his survey of the literature on economics and religion, argues that the study of religion represents "new territory" in the field of economics, while Guiso, Sapienza, and Zingales (2002, p. 2) assert that "the importance of religion in explaining the prosperity of nations seems to be experiencing a rebirth." In a similar manner, Dark (2000), foresaw increasing attention being paid to religion in the field of global economic relations. In contrast, Philpott (2002, p. 67) maintains that up until the events of September 11, most politicaleconomy scholars have long assumed that religion is not among the factors that influence states' actions in the global arena.

It is well documented that religious participation in the United States greatly exceeds that of other advanced economies. ${ }^{1}$ Religious denominations in the United States, as non-state actors, have the will and assets to initiate and affect political action and, based on their particular beliefs, have specific preferences on issues such as abortion and same-sex marriage and lobby actively to shape policies on these issues. Though less evident on the world stage, religious denominations and organizations have demonstrated effectiveness in shaping international policy actions. A recent example is the successful drive for debt relief of the poorest nations. Naming the effort after the Jubilee concept of the Old Testament (Leviticus, in which slaves are freed and landed property is periodically returned to the original owner) enabled the building of a broad coalition of faiths. This coalition, in turn, facilitated a highly visible and sustained public pressure campaign. $^{2}$

Another trend in religious participation in the United States is the surge in the membership of conservative Protestant churches and the decline in membership of more moderate denominations.

According to Coreno (2002), most sociologists and historians believe that the growth of fundamentalism is a reaction to the consequences of modernization and the secularization of religious practices. In an attempt to defend American culture from encroaching secularism, individuals form small but interconnected denominations and enclave communities, thereby separating themselves from mainstream churches and a secular world.

International Interactions, Vol. 31, No. 4 (2005): pg. 273-301. DOI. This article is @ Taylor \& Francis (Routledge) and permission has been granted for this version to appear in e-Publications@Marquette. Taylor \& Francis (Routledge) does not grant permission for this article to be further copied/distributed or hosted elsewhere without the express permission from Taylor \& Francis (Routledge). 
Over the past few decades the process of globalization has fostered ever increasing social interaction and socioeconomic change. Held et al. (1999) claim that many people see the sheer scale of contemporary social and economic change brought about by globalization as beyond the capacity of national governments and individuals to control or resist. According to Little (2003, p. ix), one view is that the negative consequences of globalization result from a marginalization of the labor movement and, therefore, a lack of a counterbalance to the "crueler aspects of corporate capitalism." One would suspect, therefore, that individuals affiliated with denominations whose origins were to defend traditionalism and resist change would have specific views toward globalization and international issues. Consider, for example, a representative statement of the United Methodist Church (2003):

The global community cannot remain passive spectators of the relentless march of a globalizing economic system which allows a few unaccountable economic and financial actors to wield excessive power at the expense of the vast majority of the world's peoples.

The United States Conference of Catholic Bishops (2002) statement on international trade maintains that:

Trade liberalization is designed to open markets and increase general economic welfare by promoting efficiency of production and hence increasing the availability and reducing the cost of goods and services. However, trade liberalization, while it may produce job gains in some areas, can produce job losses and family and community dislocation in other areas and can also lead to environmental degradation. There is also a growing concern that trade rules may unduly benefit investors in some countries to the detriment of workers and the economies of poorer countries creating a widening gap between rich and poor. Coupled with growing international financial instability, trade has moved from being considered a technical matter to a political one.

Coalitions of religious adherents in the United States have demonstrated the ability to influence national elections, as seen in the last Republican primary (see Reichley, 2002). They also wield enormous economic power as collective shareholders and thereby the

International Interactions, Vol. 31, No. 4 (2005): pg. 273-301. DOI. This article is @ Taylor \& Francis (Routledge) and permission has been granted for this version to appear in e-Publications@Marquette. Taylor \& Francis (Routledge) does not grant permission for this article to be further copied/distributed or hosted elsewhere without the express permission from Taylor \& Francis (Routledge). 
ability to shape corporate governance structures and auditing of social responsibility. The international relations literature continues to develop models of how collective preferences of societal actors result in state policy outcomes, and offers much promise in understanding how growing religious participation and evangelicalism may constrain international economic policymaking. (See, for example, Bearce, 2003 for a review of the theory and evidence of how societal preferences affect monetary policy outcomes.) Of equal interest is the question of how the beliefs of various denominations are translated into social preferences of their adherents (see, for example, Johnston, 2001). It is also important, however, to first determine if individuals affiliated with various denominations have identifiable global-policy preferences, and if so, what these preferences might be.

Of course there are numerous empirical studies on the link between religious affiliation and individual attitudes toward social and economic policies. Nonetheless, the body of empirical evidence provides mixed results on the link between religious orthodoxy and economic and political conservatism. These studies, however, focus on domestic social policies such as domestic income inequality, income redistribution, and welfare programs. There is also a substantial body of research on individual attitudes toward international economic policies, the most recent of which focus on two common theories or models of international trade policy preferences-the Ricardo-Viner (RV) model and the Heckscher-Ohlin ( $\mathrm{H}-\mathrm{O})$ model. Both theories consider the effect of increased trade on input factors' returns and provide a framework to explain how individuals evaluate the effect of opening trade on their income. (See Scheve and Slaughter, 2001a and 2001b, for a survey of this literature.)

The different outcomes of these competing models can be illustrated as follows: If we assume that the United States is relatively abundant with high-skilled labor, the $\mathrm{H}-\mathrm{O}$ model predicts that highskilled workers in the U.S. would support free trade while low-skilled workers would not. According to the R-V model, workers employed in comparative advantage sectors would support free trade, while those employed in comparative disadvantage sectors would not. Scheve and Slaughter (2001a and 2001b) employ individual-level survey data for the United States to identify if individual skill level or factor type is a

International Interactions, Vol. 31, No. 4 (2005): pg. 273-301. DOI. This article is @ Taylor \& Francis (Routledge) and permission has been granted for this version to appear in e-Publications@Marquette. Taylor \& Francis (Routledge) does not grant permission for this article to be further copied/distributed or hosted elsewhere without the express permission from Taylor \& Francis (Routledge). 
significant determinant of trade-policy preferences. The authors find that factor type rather than sector of employment influences trade policy preferences. Daniels and von der Ruhr (2003) directly extend the analysis of Scheve and Slaughter to ten advanced economies. Using both education and relative earnings as alternative measure of individual skill level, they find that skill is a robust determinant of individual preferences on immigration policies. In two additional and broader cross-country working papers, Mayda and Rodrik (2001) apply ordered estimation techniques to explain attitudes toward trade and immigration and find support for the factor endowment model.

What is yet to be given systematic study, however, is the link between religious affiliation and attitudes toward global policies. Gay (1991) is one of the few exceptions to this, and yet his assessment of the evangelical debate over capitalism is based on statements by "intellectuals" and admittedly not rank and file members. Focusing on statements of organizational leaders has led some scholars to dismiss the possibility of a link between religious affiliation and attitudes on international policies. This position rules out the possibility that the main commodities of religious denominations, religious beliefs, affect individual attitudes and in turn manifest themselves in international policy preferences that are not necessarily consistent with the views of an organization's Bishops or leading intellectuals. In contrast, we follow the most recent literature which focuses less on the causal relationship between religion and economic attitudes and on the transformative potential of religion. Guiso, Sapienza, and Zingales (2002) provide a survey of this theoretical literature on the causal link and conclude that religious beliefs are low frequency variables-based on religious teachings and conditioned by the cultural environment of the religion-that affect adherents' attitudes toward the economic system and do not necessarily reflect literal messages found in sacred texts or in statements by religious leaders.

The purpose of this paper is to explore the relationship between religious affiliation and individual preferences toward specific international policies. Implicitly we follow the approach of Guiso, Sapienza, and Zingales toward the relationship between religion and economic attitudes. Also, we are similar to Milner's (1988) approach to understanding protectionist attitudes: We do not account for 
international policy outcomes, and we do not contend that we have fully explained individual international-policy preferences. Rather, we argue that the impact of an individual's religious affiliation plays an important and understudied role in shaping individual internationalpolicy preferences. Specifically, our hypotheses are: (1) There is a significant relationship between an individual's religious affiliation and their international-policy preferences. (2) Because the United States is a multi-denominational society, the relationship between affiliation and policy preferences varies across denominations. (3) Conservative Protestants, especially those in the southern region of the United States, maintain a stronger commitment to separatism (as argued by Coreno, p. 338) and, therefore, are more likely to display anti-globalist policy preferences.

To explore these hypotheses, we examine International Social Survey Program (ISSP) data on national identity and augment it with the General Social Survey (GSS) data to obtain the individual respondent's religious affiliation. Our four empirical models employ survey questions on imports, immigration, the role of international institutions, and unilateral policy actions. Our results, in general, show that religious affiliation is indeed a significant determinant of international policy preferences and that individuals affiliated with conservative Protestant denominations are more likely to support positions on international issues that can be regarded as consistent with the nationalist-protectionist right. That is, they are more likely to agree with polices that restrict imports and reduce immigration, more likely to oppose granting enforcement rights to international institutions, and more likely to agree with unilateral policy actions. We also find, however, that individuals affiliated with the United Methodist Church-the third largest religious organization in the United States and one typically considered liberal to moderate in its theological orthodoxy-also are more likely to support policies that restrict imports. In addition, we find evidence of a reinforcing regional effect and differences between African American Baptists and non-Baptist African Americans on the issues of imports, and granting enforcement rights to international institutions. In total we take this as evidence of a relationship between an individual's religious affiliation and their preferences toward international policies, suggesting that religious-

International Interactions, Vol. 31, No. 4 (2005): pg. 273-301. DOI. This article is @ Taylor \& Francis (Routledge) and permission has been granted for this version to appear in e-Publications@Marquette. Taylor \& Francis (Routledge) does not grant permission for this article to be further copied/distributed or hosted elsewhere without the express permission from Taylor \& Francis (Routledge). 
based social teaching may indeed affect individual views on global economic issues.

In the next section we summarize the literature on religious participation and economic and political attitudes. In that section we also outline the literature on the conservative to liberal continuum of Protestant denominations. Next we describe the survey data used in our empirical analysis. The following section provides the results of the analysis and a conclusion is then offered.

\section{The Link Between Religious Affiliation And Economic And Political Attitudes}

In an extensive survey, Iannaccone (1998) separates studies of economics and religion into three categories. The first line of research deals with the micro-foundations of religious participation, the second addresses the economic consequences or outcomes of religious participation, while the third line of research invokes religious teachings to critique economic policies. This study is in keeping with the second area of research and, for space considerations, the reader is otherwise referred to Iannaccone. This section briefly outlines some of the important contributions on the link between religious participation, theological orthodoxy and economic conservatism, and individual attitudes toward international economic policies.

\section{A. Religious Participation and Economic Outcomes}

There are a number of prominent empirical studies of the consequences of religious affiliation. Lowry (1998), for example, considers religious participation and the individual's choice of membership in environmental groups. The premise is that religious affiliation is a measure of an individual's beliefs about "the good society" and is therefore reflected in the specific policies the affiliation espouses. Lowery also argues that the strength of an individual's religious affiliation may, in turn, affect the degree of their policy convictions. Testing state-level data, he finds that the number of members of Judeo-Christian denominations per household has a negative and significant effect on membership rates to groups advocating public policies in favor of environmental preservation. 
Further, his results suggest that religious affiliation positively affects membership to sportsmen groups advocating private stewardship of natural resources.

Glaeser and Glendon (1998) test Max Weber's view thatbecause of the Calvinism dogma of predestination versus Catholicism dogma of free will-economic growth of Protestant nations exceeds that of Catholic nations. They find that, on average, Protestant religious beliefs are conducive to higher per capita income and growth after controlling for individual characteristics such as health status, age, gender, education, income, and perceived social status, as well as country fixed effects. Barro and McCleary (2003) find that economic growth responds positively to enhanced religious beliefs, but negatively to increased participation, even while controlling for possible reverse causation. In a similar manner, Mehanna (2003) finds that countries whose dominant faith is Protestant tend to be more open, in terms of trade, than Catholic or Muslim nations.

Guiso, Sapienza, and Zingales (2002) examine the impact of religion on attitudes toward several issues including trust of government, women working, and thriftiness. They find that religious beliefs are associated with "good" economic attitudes and that religious effects differ across major religious denominations. Dahl and Ransom (1999) consider the importance of the strength of religious affiliation-or religiosity-in the presence of economic self-interest by surveying members of the Church of Jesus Christ of Latter-Day Saints on tithing beliefs. Their premise is that devout members, defined by church attendance, are less likely to allow financial self-interest to affect their definition of income for tithing purposes. While they find a pattern that more frequent churchgoers appear less self-serving than infrequent churchgoers, their likelihood ratio statistics are insignificant.

\section{B. Theological Orthodoxy and Economic Conservatism}

There are numerous empirical studies on the link between religious conservatism and economic and political conservatism. As discussed and summarized by Pyle (1993), groups such as the Moral Majority reinforce a public perception that Christian conservatism is tied to conservative political and economic attitudes. The assumption 
is that, on the one hand, individuals affiliated with conservative denominations are opposed to progressive government expenditure programs designed to reduce social inequality. On the other hand, individuals affiliated with liberal denominations are more accepting of such programs.

A common hypothesis underlying this opinion is that conservatives tend to believe that social change should come about through the conversion of the individual as opposed to reform of economic and social policies. Pyle concludes that there is little consensus on the issue, yet argues that social class, race, and political ideology take precedent over religious orientation, but once controlling for these factors, religious affiliation still matters and theological conservatism is likely related to conservative attitudes toward government assistance programs. His analysis, however, finds the opposite in that theological liberalism is less likely to predict support government restructuring programs. His results are not unique as a number of other studies (see Iannaccone, 1993 for example) which found that adherents of conservative denominations are more likely to support government support policies.

Specific to this study, there is the additional difficulty of associating international policy preferences with liberal or conservative political ideologies. As argued by Giddens (1994), the left-right political ideology distinction may not retain any meaning when applied to anything outside of conventional political issues, such as globalization. Even so, Steger (2001) argues that there remain significant differences between the anti-globalists on the left and right to differentiate between the two, branding the conservative antiglobalist camp as the nationalist-protectionists

Coreno (2002) argues that in order to defend radical traditionalism against the penetration of secular values; conservative Protestants often form small, interconnected-yet independentenclave communities. By forming enclave communities they are able to separate themselves, as much as possible, from the encroachment of secular change. Barro and McCleary also theorize that religion may influence the propensity to interact with outsiders in domestic or international business and, therefore, affect a country's degree of 
openness. Hence, we hypothesize that conservative Protestants are more likely to display nationalist-protectionist attitudes such as favoring policies that restrict imports and immigration, supporting unilateral policy actions, and opposing rights being granted to international organizations.

\section{Survey Data}

In order to examine the relationship between affiliation and international-policy issues, we employ the results of a survey conducted and compiled by Zentralarchiv für Empirische Sozialforschung as part of the International Social Survey Program. The survey is titled ISSP: National Identity and available through the Inter-University Consortium for Political and Social Research (ICPSR). ${ }^{3}$ We augment this data with the General Social Survey (GSS) component which divides the main Protestant religions into twentyeight sub-denominations. In this section we describe the dependent and independent variables used in the analysis and the treatment of missing observations.

\section{A. Missing Data}

Our first difficulty lies in addressing the problem of missing values, a common problem in empirical treatments of survey data. (The number of missing values for the data used here can be found in Tables 1 and 2.) There are basically two approaches to handling missingness. The first approach is to omit the cases with missing values via listwise deletion. Listwise deletion, however, may result in biased estimates if the deleted cases systematically differ from the observed cases, and also reduces the efficiency of estimates because important information is lost.

The most common alternative to listwise deletion is to impute values for missing data. This approach does not assume that the missing data is missing at random as does listwise deletion, rather it generates correct uncertainty estimates conditional on the data used to impute missing values. To generate data sets with imputed values for missing data we use the EMis algorithm of Amelia: A Program for Missing Data, by Honaker et al. (2000). The reader is referred to King 
et al. (2001) for a detailed description of the advantages of this approach and the EMis algorithm.

The process of imputing values involves three steps. The first step is to generate multiple data sets containing imputed values for missing data. Based on the size of our data set and following King et al. (2001), we generate five data sets that are used for all applications in this study. The second step is to estimate a regression model for all of the imputed data sets, thereby creating multiple coefficient estimates. The final step is to combine the estimated coefficients and standard errors.

\section{B. Description of the Dependent Variables}

Responses for the following survey items are the dependent variables of our analysis. The survey items are:

1. How much do you agree or disagree with the following statement: The United States should limit the import of foreign products in order to protect its national economy.

2. How much do you agree with the following: For certain problems like environment pollution, international bodies (e.g., the United Nations, European Union, World Health Organization) should have the right to enforce solutions.

3. How much do you agree or disagree with the following statement: The United States should follow its own interest, even if this leads to conflicts with other nations.

4. Do you think the number of immigrants to the United States nowadays should be ...

For the first three items individuals could select agree strongly, agree, neither agree nor disagree, disagree, disagree strongly, or refuse to choose. For the final item, individuals could select increased a lot, increased a little, remain the same, reduced a little, reduced a lot, or refuse to choose. Table 1 provides the summary data on the dependent variables. It is important to note that using policy-oriented questions implicitly assumes that the respondent has some understanding of the effects of these policy changes on their individual welfare.

International Interactions, Vol. 31, No. 4 (2005): pg. 273-301. DOI. This article is @ Taylor \& Francis (Routledge) and permission has been granted for this version to appear in e-Publications@Marquette. Taylor \& Francis (Routledge) does not grant permission for this article to be further copied/distributed or hosted elsewhere without the express permission from Taylor \& Francis (Routledge). 
NOT THE PUBLISHED VERSION; this is the author's final, peer-reviewed manuscript. The published version may be accessed by following the link in the citation at the bottom of the page.

\section{Description of the Independent Variables}

Following the literature cited in this study, we control for a number of factors that may shape an individual's views on international policies. In general, we control for demographics, individual skill level, and political ideology, while testing the significance of religious affiliation and religiosity. Each variable is described below.

\section{Demographic, Political Ideology, and Skill Level}

Female is a dichotomous variable that takes the value of unity for female and zero for male, and Age is a continuous variable, measured in years. The studies discussed above find evidence, though not consistently significant, indicating that women are more likely to support restrictions on trade. In addition, Kull (1998) reports that women are more likely to support international engagement that is based on partnership and cooperation as opposed to unilateral action policy actions. The evidence on age is mixed.

African American is a dichotomous variable that takes the value of unity if the respondent is African American, and zero otherwise. Hispanic is a dichotomous variable that takes the value of unity if the respondent is Hispanic, and zero otherwise. Though previous studies show that race is an important determinant of support for domestic social policies, Kull (1998) concludes that race plays a limited role in shaping views on international policies. Union indicates if the respondent and / or their spouse is a member of a trade union with a value of unity, and zero otherwise. Major trade unions in the United States have very specific views on negative consequences of international trade and, therefore, union members are more likely to be opposed to international trade. At the same time, the major trade unions are favorable on legal immigration and so we do not expect union members to oppose immigration.

Social Class is the respondent's view of their social status and is a categorical variable that ranges from 1 for lower class to 5 for upper class. We expect that individuals that identify with lower social classes are more likely to feel threatened by globalization, specifically trade

International Interactions, Vol. 31, No. 4 (2005): pg. 273-301. DOI. This article is @ Taylor \& Francis (Routledge) and permission has been granted for this version to appear in e-Publications@Marquette. Taylor \& Francis (Routledge) does not grant permission for this article to be further copied/distributed or hosted elsewhere without the express permission from Taylor \& Francis (Routledge). 
and immigration. Similar to the studies cited earlier, we model political ideology with a categorical variable that ranges from unity, indicating someone who views their political ideology as far left, to five, indicating someone views their political ideology as far right.

Scheve and Slaughter (2001b) show that, once controlling for political ideology and demographic characteristics, either education or earnings are appropriate measures of labor market skills and should be included as an economic factor as opposed to a demographic factor. Education and earnings, however, should not be included in the same model. Because of space consideration and the number of missing values that were imputed for earnings ( 423 for earnings versus 4 for education), we use education as a proxy measure of individual skill throughout this paper. Nonetheless, in general our results are the same for either education or earnings and for including both variables at the same time. Hence, our measure of skill level is a continuous variable that indicates the number of years of schooling the respondent has completed. The demographic, political ideology, and skill variables are summarized in Table 2.

\section{Religious Affiliation}

The survey asked individuals if they belonged to a major religious group. There were approximately thirty denominations that respondents could identify with including Catholic, Jewish, various Protestant denominations, other Christian denominations, and nonChristian denominations. Individuals were also allowed to select no affiliation or to refuse to answer. Only two individuals refused to answer and were removed from the sample. (In other words, we did not impute missing values for affiliation.) Individuals with no religious affiliation serve as the base group for all of our regression analysis. There were no responses to categories other than Catholic, Protestant, other Christian and Jewish. The distribution of the sample among the major denominations is illustrated in Figure 1. In the United States the ISSP is administered as part of the GSS. The GSS section of the ISSP further breaks down the major Protestant denominations into an additional twenty-eight sub-denominations, such as Southern Baptist, United Methodist, and so on.

International Interactions, Vol. 31, No. 4 (2005): pg. 273-301. DOI. This article is (C) Taylor \& Francis (Routledge) and permission has been granted for this version to appear in e-Publications@Marquette. Taylor \& Francis (Routledge) does not grant permission for this article to be further copied/distributed or hosted elsewhere without the express permission from Taylor \& Francis (Routledge). 
The National Opinion Research Center (NORC) sorts these subdenominations into a topology of liberal, moderate, or conservative, based upon scales of orthodoxy, biblical inerrancy, and denominational differences on being born again. ${ }^{4}$ We shall refer to this particular classification system as NORC in our regression analysis. Roof and McKinney (1987) provide an alternative classification system (see Coreno and Pyle, op. cit., as examples of the application of this system), which we shall refer to as RM throughout. The two main differences between RM and NORC are: RM focuses on regional differences, so that Baptists are divided into those who live in the south (Census definition) and those who do not, while NORC focuses on sub-denominations, e.g., Southern Baptist Convention is separated from the American Baptist Association and so on. Secondly, by focusing on denominations, NORC divides the sub-denominations of a major denomination across the liberal to conservative continuum. Roof and McKinney, in contrast, use a regional approach to divide adherents into a continuum of sub-denominations. We augment the NORC system by isolating the second and third largest denominations in the United States, Southern Baptist and United Methodist respectively, and augment the RM system by separating Methodists in the same regional manner as Baptists.

\section{Results}

Our objective is to determine if an individual's religious affiliation holds any additional insight into their international-policy preferences. Our approach, therefore, is to add religious affiliation and religiosity to the models of international-policy preferences found most recently in the literature, thereby controlling for other important individual demographic, economic, and political characteristics.

In our empirical analysis the possible responses to the survey questions are modeled as ordered choice models with five possible answers as detailed in Table 1. Given that the multiple categories of responses to the survey questions follow a natural order, we employ ordered probit (OP) estimation techniques. The five imputed data sets were used to generate the OP estimates for every model. Following Honaker et al., (2000), model coefficients are the mean estimates of the five imputed data sets. The standard errors are found by averaging the mean standard error across the five data sets, combining this

International Interactions, Vol. 31, No. 4 (2005): pg. 273-301. DOI. This article is @ Taylor \& Francis (Routledge) and permission has been granted for this version to appear in e-Publications@Marquette. Taylor \& Francis (Routledge) does not grant permission for this article to be further copied/distributed or hosted elsewhere without the express permission from Taylor \& Francis (Routledge). 
value with the standard error across the five data sets, which is adjusted for the fact that the number of observations is less than infinity. We, therefore, not only allow for uncertainty of the point estimates, but also for the uncertainty of the imputed values.

\section{A. Base Model Results}

Table 3 provides the results of a base model to facilitate comparisons with the literature cited above. The results indicate that older respondents, union members, individuals that identify with lower social classes, and African Americans are more likely to support policies that restrict imports, while higher-skill individuals and Hispanics are more likely to disagree. Older individuals and individuals who identify their political ideology to the right are more likely to disagree with international institutions having enforcement rights. Females and higher-skill individuals are more likely to disagree with a nation acting unilaterally. Older respondents, individuals who identify their political ideology to the right, and individuals who identify with lower social classes are more likely to prefer restricting immigration, while higher-skill individuals and Hispanics are more likely to favor increasing immigration levels. ${ }^{5}$

\section{B. Religious Affiliation}

Table 3 also provides results for each model when the major religious denominations and a religiosity measure are added. These results show that Catholics, Baptists, Methodists, Presbyterians, and individuals affiliated with denominations that fall into the broad category of "other Protestant" are more likely to support policies that restrict imports. Lutherans and other Protestants are more likely to disagree with international institutions having enforcement rights, while Jews and Baptists are more likely to agree with a nation acting unilaterally. None of the major denominations are significant in the regression on immigration.

In addition to the results described above, the results for African Americans (in regard to imports) appear to be sensitive to the inclusion of religion controls. We suspect that this reflects the possibility that religious affiliations have a differential effect within

International Interactions, Vol. 31, No. 4 (2005): pg. 273-301. DOI. This article is @ Taylor \& Francis (Routledge) and permission has been granted for this version to appear in e-Publications@Marquette. Taylor \& Francis (Routledge) does not grant permission for this article to be further copied/distributed or hosted elsewhere without the express permission from Taylor \& Francis (Routledge). 
race. Subsequent regressions attempt to flesh this out through the use of cohort groups for African Americans. The results for age also show some sensitivity to the additional variables (see the imports and institutions models in particular), specifically because of the greater religiosity of older respondents. ${ }^{6}$ Inglehart (1990) suggests that the difference in religiosity across age may be due to a cultural shift. We were unable, however, to identify a specific point in time when this shift might have occurred, consistent with Inglehart's claim (p. 4) that such shifts are gradual. ${ }^{7}$ This finding is also consistent with the empirical evidence showing that religiosity increases with age even when controlling for time periods and cohort effects (Hout and Greeley, 1987, p. 328, as cited in Iannaccone, p. 1474).

\section{Sub-Denominations Liberal to Conservatism Classifications}

The lack of uniformity in the results across denominations reveals the importance of disaggregating the major denominations and the failure to do so is likely the reason that related studies that aggregate denominations do not find religion to be important. ${ }^{8}$ In order to better understand how religious affiliation relates to international-policy preferences, we classify denominations based on the NORC and RM classification schemes.

Table 4 provides the results for the NORC system. In addition, cohorts groups are created for African Americans who are Baptists (55 percent of African Americans in our sample are Baptist) and for African Americans who are not Baptist. The Hispanic variable is robust to the inclusion of religious affiliation controls so, given the small number of observations, we do not create cohort groups for Hispanics. The results in Table 4 indicate a differential effect among African Americans in that African-American Baptists are more likely to support restrictions on trade and non-Baptist African Americans are more likely to oppose international institutions having enforcement rights. The results in Table 4 also show that liberal Protestants, conservative Protestants, and "other" Protestants are more likely to support policies that restrict trade, and conservative Protestants, and "other" Protestants are more likely disagree with international institutions having enforcement 
rights. Conservative Protestants are also more likely to agree with a nation acting unilaterally.

The largest religious denominations in the United States (and in our sample) are Catholic, Southern Baptist, and United Methodist, respectively. Under the NORC system, United Methodists are categorized as liberal and Southern Baptists as conservative (whether or not the individual resides in the south). To determine if United Methodist is driving the liberal Protestant results and Southern Baptist the conservative Protestant results, we separate these denominations from their respective categories and retest each model. The results show clearly that the United Methodist denomination is driving the results on the trade: It is United Methodists that are more likely to support restrictions on trade, while the remaining liberal Protestant denominations are not statistically different from the base group. Southern Baptists, in contrast, are not driving the results for imports, but display differential effects relative to conservative Protestants across the other three models in that other conservative Protestants are more likely to disagree with granting enforcement rights to international institutions but Southern Baptists are not, while Southern Baptists are more likely to agree with unilateral policy actions and restricting levels of immigration.

As an alternative to the NORC classification system, Table $\underline{5}$ provides results for the RM classification system. One significant difference between the NORC and RM systems is that RM focuses on a regional dimension and allows us to test our third hypothesis. Specifically, Baptists are separated into two groups, Baptists, regardless of whether they are Southern Baptists, who reside in the South Region and all other Baptists. The reason for this separation is due to the strong fundamentalist and evangelical dominance of the region (Coreno, 2002). Another difference between the two systems is that the RM categories of Liberal and Moderate are based on the major denominations as opposed to sub-denominations. Hence, all Presbyterians are categorized as liberal and all Methodists and Lutherans are categorized as moderate even though when considering scales of orthodoxy and biblical inerrancy, some sub-denominations within both are considered conservative Protestants and others liberal.

International Interactions, Vol. 31, No. 4 (2005): pg. 273-301. DOI. This article is @ Taylor \& Francis (Routledge) and permission has been granted for this version to appear in e-Publications@Marquette. Taylor \& Francis (Routledge) does not grant permission for this article to be further copied/distributed or hosted elsewhere without the express permission from Taylor \& Francis (Routledge). 
Results for the RM system differ from the NORC system in that moderate Protestants are significant in the imports model whereas liberal Protestants are not, and conservative Protestants are not significant in the institutions model. Disaggregating the major denominations or separating out Southern Baptists and United Methodists would simply lead us to the results found with the NORC system in Table 4, resolving the differences just mentioned. ${ }^{9}$ Instead, the second set of regressions in Table $\underline{5}$ increases the regional dimension of the analysis by separating Methodists and other Protestants in non-south and south cohort groups as a proxy means of capturing conservative Protestants influences that dominate the south region.

The results show that Methodists are driving the results for moderates on the trade question but standard hypothesis tests indicate that there is no statistical difference between non-south and south Methodists. In contrast there is evidence of a statistically significant difference between south Methodists and non-south Methodists, with the former more likely to favor policies reducing immigration. Differences also exist between non-south Baptists and south Baptists, with the latter more likely to favor restrictions on imports and unilateral policy actions. The remaining regional aspects are the difference between non-south and south, other Protestants with the former more likely to oppose the rights of international institutions and the latter more likely to support policies that restrict imports, and the difference between remaining moderate Protestants (after Methodists and non-south Baptists are removed) and Methodists and non-south Baptists, as the remaining moderate Protestants are more likely to support the role of international institutions. Hence, the results in Tables 4 and $\underline{5}$ indicate evidence of both affiliation and regional effects. If the regional dimension does indeed proxy for a conservative dominance in the south, then again, in general, this supports the notion that conservative Protestant denominations, particularly those in the south, are more likely to display policy preferences that can be labeled as nationalistic-protectionist. 
NOT THE PUBLISHED VERSION; this is the author's final, peer-reviewed manuscript. The published version may be accessed by following the link in the citation at the bottom of the page.

\section{Simulations}

The magnitude of coefficients of ordered choice models are notoriously difficult to interpret. To better understand the relative impact of religious affiliation, we simulate the marginal effects of religious affiliation for the second set of regressions of the NORC classification system in Table 4 (along the lines suggested in King et al., 2000). To do so, Monte Carlo simulations are conducted using Clarify: Software for Interpreting and Presenting Statistical Results (Tomz et al., 2001). The process involves drawing 1,000 simulated parameters from an asymptotic sampling distribution that is multivariate normal, and whose mean is equal to the vector of parameter estimates and variance equal to the variance-covariance matrix of estimates. Next the simulated parameters are used to calculate two sets of probabilities. First, all explanatory variables are set at their mean value, except for the religious affiliation variables that are set at zero. In other words, every individual in all five imputed data sets is treated as if they have no religious affiliation. From this we generate the predicted probability of response to each category of the survey question. Next, we change every individual's affiliation to, say, United Methodist, and repeat the simulation generating new predicted probabilities. The differences in these predicted probabilities-the marginal effects-are illustrated in Figures $\underline{2} \underline{3} \underline{4}$ through $\underline{5} \cdot{ }^{10}$ To better illustrate the relative importance of religious affiliation, we also include education (for models 1, 2, and 4) and political ideology (for model 3) as benchmarks. With respect to education we set all variables to their mean value and all affiliation variables to zero (a mean-value nonbeliever). We then increase education by one standard deviation, from approximately 13 years to 16 years of education, and simulate the new probabilities. The same process is used for political ideology, moving the individual from approximately 2.9 , or "center," to 3.9 , or "right."

Figure 2 shows the change in probabilities for the question on restricting imports to the United States. The shift from left to right that occurs moving up the vertical axis illustrates how an affiliation with a particular group increases the probability that an individual will agree with policies that restrict imports. The figure shows that the magnitude of effect is largest for African American Baptists (whereas non-Baptist

International Interactions, Vol. 31, No. 4 (2005): pg. 273-301. DOI. This article is @ Taylor \& Francis (Routledge) and permission has been granted for this version to appear in e-Publications@Marquette. Taylor \& Francis (Routledge) does not grant permission for this article to be further copied/distributed or hosted elsewhere without the express permission from Taylor \& Francis (Routledge). 
African American was not statistically different from the base group) as the probability that an individual agrees strongly that the U.S. should restrict imports increases by more than 15 percent and the probability they strongly disagree falls by more than 2 percent. The next largest shifts occur for Southern Baptists and United Methodists, respectively. For most response categories, affiliation effects are larger than three additional years of education.

Figure 3 illustrates the effects of religious affiliation on preferences toward the enforcement rights of international institutions. Again there is a differential effect among African Americans. NonBaptists African American, labeled "other," increases the probability that an individual will disagree strongly that international institutions should have enforcement rights by nearly 3 percent and reduces the probability that they will agree strongly by more than 10 percent. Other Protestant and Conservative Protestant are only slightly smaller in magnitude. These particular affiliation effects are greater than a shift in political ideology from centre to right.

Figure 4 displays the effects of Southern Baptist and Jewish on preferences toward unilateral policy actions. As the figure shows, Southern Baptist has a slightly stronger effect than Jewish, increasing the probability by more than 9 percent that an individual will strongly agree, whereas Jewish increases the probability by more than 8 percent. Both effects are relatively larger than the effect of three additional years of education.

Figure 5 shows the impact of Southern Baptist on immigration preferences, in which Southern Baptist decreases the probability that an individual prefers increasing immigration a lot by nearly 2 percent and increases the probability that they prefer that immigration be reduced a lot by more than 14 percent. The affiliation effect is larger across all response categories than three additional years of education.

\section{Conclusion}

Rising church membership rates and the resurgence of evangelical Christianity have proved religion to be an important cultural force in the United States. In turn, there has been a renewal permission has been granted for this version to appear in e-Publications@ Marquette. Taylor \& Francis (Routledge) does not grant permission for this article to be further copied/distributed or hosted elsewhere without the express permission from Taylor \& Francis (Routledge). 
of interest among political economists on the connection between religion and economic outcomes. In this paper we investigate the linkage between religious affiliation and individual international-policy preferences. Our results provide evidence of such a relationship in that conservative Protestants, particularly those in the south, are more likely to display anti-globalist views. That is, they are more likely to agree with polices that restrict imports, and reduce immigration, more likely to oppose granting enforcement rights to international institutions, and more likely to agree with unilateral policy actions. We also find differential affects of religious affiliation among African Americans as African American Baptists are more likely to support restrictions on imports than non-Baptist African Americans and the latter is more likely to oppose granting enforcement rights to international institutions than the former.

Based on our results, we conclude that religion does matter and that the impact is far from uniform. It is our hope that this paper will motivate greater interest in the relationship between religion and international policy. We suggest that, when the 2003 ISSP survey is completed and compiled, future studies should extend both across time to detect possible shifts in cultural norms and cross-country differences. In addition, future research should also focus on the mechanism through which religious beliefs and religious participation affect international-policy preferences (perhaps along the lines posited by Montgomery, 1996) as well as the process by which these preferences move toward policy outcomes (such as Bearce, 2003).

This paper benefited greatly from the comments of Marc von der Ruhr, Jim McGibany, Larry Iannaccone, Rob Toutkoushian, and two anonymous referees.

\section{Notes}

${ }^{1}$ For data on religious organization and participation, see the American Religion Data Archive at Pennsylvania State University, www.thearda.com

2 According to John Carr, chief legislative strategist for the Catholic Bishops' Conference, the debt relief program would not have materialized without the leadership of the religious community (Reichley, 2002). The efforts of Jubilee 2000 were most visible during the Denver G7

International Interactions, Vol. 31, No. 4 (2005): pg. 273-301. DOI. This article is @ Taylor \& Francis (Routledge) and permission has been granted for this version to appear in e-Publications@Marquette. Taylor \& Francis (Routledge) does not grant permission for this article to be further copied/distributed or hosted elsewhere without the express permission from Taylor \& Francis (Routledge). 
and Birmingham G8 summits, culminating in the Cologne initiative in 1999.

${ }^{3}$ Independent institutions in each country collected the data for the ISSP. Neither the original collectors nor the ZENTRALARCHIV bear any responsibility for the analyses or interpretation presented here.

${ }^{4}$ See Smith (1990) for a description of the process and the predictive power of these classifications.

${ }^{5}$ Scheve and Slaughter (2002a and 2003b) do not find region controls to be significant in regressions on import restrictions nor controls for "gateway communities" to be significant in regressions on immigration levels. Daniels and von der Ruhr (2003) deal with the collinearity of religious denominations and regional controls. They find that regional controls tend to capture the effects of a region's dominant religion and become insignificant when this is accounted for. Because the introduction of sub-denominations introduces this regional aspect, we avoid the direct use of regional controls in all of the models.

6 The correlation coefficient between the two variables was approximately 20 percent, which is statistically significant at less than the 1 percent level.

${ }^{7}$ We created different cohorts and tested each model three times with the various cohort dummies. The cohort groups are those born before 1957 and after, before 1962 and after, and before 1967 and after. Regardless of how we modeled the break in age, none of the cohort dummies were statistically significant.

${ }^{8}$ Alesina and Ferrara (2002), for example, do not find religion to be a significant determinant of individual trust in others. Disaggregating of Protestant denominations may prove to be an interesting direction for that line of research.

${ }^{9}$ For example, separating out the Presbyterian denominations classified as conservative under the NORC system would render the category of liberal Protestants insignificant.

10 The actual predicted probabilities, the standard errors, and 90 percent confidence intervals are available upon request.

\section{References}

Alesina, Alberto and La Ferrara, Eliana. 2002. Who Trusts Others. Journal of Public Economic, 85: 207-234.

Barro, Robert J. and McCleary, Rachel M. 2003. Religion and Economic Growth Across Countries. American Sociology Review, 68: 760781. No.5

International Interactions, Vol. 31, No. 4 (2005): pg. 273-301. DOI. This article is @ Taylor \& Francis (Routledge) and permission has been granted for this version to appear in e-Publications@Marquette. Taylor \& Francis (Routledge) does not grant permission for this article to be further copied/distributed or hosted elsewhere without the express permission from Taylor \& Francis (Routledge). 
Bearce, David H. 2003. Societal Preferences, Partisan Agents, and Monetary Policy Outcomes. International Organization, 57: 373410. Spring

Coreno, Thaddeus. 2002. Fundamentalism as a Class Culture. Sociology of Religion, 63(3): 335-360. Spring

Dahl, Gordon B. and Ransom, Michael R. 1999. Does Where You Stand Depend on Where You Sit? Tithing Donations and Self-Serving Beliefs. American Economic Review, 89(4): 703-727.

Daniels, Joseph P. and von der Ruhr, Marc. 2003. The Determinants of Immigration-Policy Preferences in Advanced Economies: A Cross-Country Study. Atlantic Economic Journal, 31(2): 146158.

Dark, K. R., ed. 2000. Religion and International Relations, New York: St. Martin's Press.

Gay, Craig M. 1991. With Liberty and Justice for Whom? The Recent Evangelical Debate over Capitalism, Grand Rapids: William B. Eerdmans Publishing Company.

Glaeser, Edward L. and Glendon, Spencer. 1998. Incentives, Predestination and Free Will. Economic Inquiry, VXXXVI July: 429-443.

Giddens, Anthony. 1994. Beyond Left and Right: The Future of Radical Politics, Stanford: Stanford University Press.

Guiso, Luigi, Paola Sapienza, and Luigi Zingales (2002). "People's Opium? Religion and Economic Attitudes," National Bureau of Economic Research, Working Paper 9237 http://www.nber.org/papers/w9237

Held, David, McGrew, Anthony, Goldblatt, David and Jonathan, Perraton. 1999. Global Transformations: Politics, Economics and Culture, Stanford: Stanford University Press.

Honaker, James, Anne Joseph, Gary King, Kenneth Scheve, and Naunihal Singh (2000). Amelia: A Program for Missing Data (Windows version), Cambridge MA: Harvard University http://Gking. Harvard.edu

Hout, Michael and Greeley, Andrew M. 1987. The Center Doesn't Hold: Church Attendance in the United States, 1940-1984. American Sociological Review, 52(3): 325-345.

Iannaccone, Laurence R. 1998. "Heirs to the Protestant Ethic? The Economics of American Conservatives". In Fundamentalism and

International Interactions, Vol. 31, No. 4 (2005): pg. 273-301. DOI. This article is @ Taylor \& Francis (Routledge) and permission has been granted for this version to appear in e-Publications@ Marquette. Taylor \& Francis (Routledge) does not grant permission for this article to be further copied/distributed or hosted elsewhere without the express permission from Taylor \& Francis (Routledge). 
the State, Edited by: Marty, Martin E. and Scott Appleby, R. 342-366. Chicago: University of Chicago Press.

Iannaccone, Laurence R. 1983. Introduction to the Economics of Religion. Journal of Economic Literature, XXXVI September: 1465-1496.

Inglehart, Ronald (1990). Culture Shift in Advanced Industrial Society, Princeton: Princeton University Press.

Johnston, Alastair Iain. 2001. Treating International Institutions as Social Environments. International Studies Quarterly, 45: 487515.

King, Gary, Tomz, Michael and Jason, Wittenberg. 2000. Making the Most of Statistical Analyses: Improving Interpretation and Presentation. American Journal of Political Science, 44(2) April: 347-361.

King, Gary, Honaker, James, Joseph, Anne and Kenneth, Scheve. 2001. Analyzing Incomplete Political Science Data: An Alternative Algorithm for Multiple Imputation. American Political Science Review, 95(1): 49-69.

Kull, Steven. 1998. Seeking a New Balance: A Study of American and European Public Attitudes on Transatlantic Issues. Program on International Policy Attitudes

Lowry, Robert C. 1998. Religion and the Demand for Membership in Environmental Citizen Groups. Public Choice, 94: 223-240.

Little, David. 2003. Spiritual Perspectives on Globalization: Making Sense of Economic and Cultural Upheaval, Edited by: Ira, Rifkin. ix-xi. Woodstock, VT: Skylight Paths Publishing.

Mayda, Anna Maria and Rodrik, Dani. Why Are Some People (And Countries) More Protectionist than Others?. Draft Paper. Cambridge, MA: Harvard University.

Mehanna, Rock-Antoine (2002). "International Trade, Religion, and Political Freedom: An Empirical Examination," Wartburg College. Mehanna, Rock-Antoine. 2003. International Trade, Religion, and Political Freedom: An Empirical Examination. Global Business and Economics Review, 5: 284-296. No. 2

Milner, Helen V. 1988. Resisting Protectionism: Global Industries and the Politics of International Trade, Princeton: Princeton University Press. 
Montgomery, James D. 1996. Contemplations on the Economic Approach to Religious Behavior. America Economic Review, 86(2) May: 443-447.

Philpott, Daniel. 2002. The Challenge of September 11 to Secularism in International Relations. World Politics, 55 October: 66-95.

Pyle, Ralph E. 1993. Faith and Commitment to the Poor: Theological Orientation and Support for Government Assistance Measures. Sociology of Religion, 54(4): 385-401.

Reichley, A. James. 2002. Faith in Politics, Washington DC: The Brookings Institution.

Roof, Wade Clark and McKinney, William. 1987. American Mainline Religion: Its Changing Shape and Future, New Brunswick: Rutgers University Press.

Scheve, Kenneth F. and Slaughter, Matthew J. 2001a. Journal of International Economics, 54: 267-292.

Scheve, Kenneth F. and Slaughter, Matthew J. 2001b. Labor Market Competition and Individual Preferences over Immigration Policy. The Review of Economics and Statistics, 83(1) February: 133145.

Smith, Tom W. 1990. Classifying Protestant Denominations. Review of Religious Research, 31 March: 225-245.

Steger, Manfred B. 2001. Globalism: The New Market Ideology, Lanham, Maryland: Rowman and Littlefield Publishers Inc.

Tomz, Michael, Jason Wittenberg, and Gary King (2001). CLARIFY: Software for Interpreting and Presenting Statistical Results, Version 2.0, Cambridge, MA: Harvard University http://gking.harvard.edu

United Methodist Church (2003). "Staying Engaged for Justice: A Statement by the Ecumenical Team to the Fourth Preparatory Committee of Financing for Development," General Board of Church and Society News www.umc.org

United States Conference of Catholic Bishops (2002). "International Trade Back-grounder," Social Development and World Peace, October.

Weber, Max. 1958. The Protestant Ethic and the Spirit Of Capitalism, New York: Charles Scribner's Sons.

International Interactions, Vol. 31, No. 4 (2005): pg. 273-301. DOI. This article is @ Taylor \& Francis (Routledge) and permission has been granted for this version to appear in e-Publications@Marquette. Taylor \& Francis (Routledge) does not grant permission for this article to be further copied/distributed or hosted elsewhere without the express permission from Taylor \& Francis (Routledge). 
NOT THE PUBLISHED VERSION; this is the author's final, peer-reviewed manuscript. The published version may be accessed by following the link in the citation at the bottom of the page.

International Interactions, Vol. 31, No. 4 (2005): pg. 273-301. DOI. This article is @ Taylor \& Francis (Routledge) and permission has been granted for this version to appear in e-Publications@Marquette. Taylor \& Francis (Routledge) does not grant permission for this article to be further copied/distributed or hosted elsewhere without the express permission from Taylor \& Francis (Routledge). 
NOT THE PUBLISHED VERSION; this is the author's final, peer-reviewed manuscript. The published version may be accessed by following the link in the citation at the bottom of the page.

\section{Appendix}

\section{Table 1. Summary Data for Dependent Variables from Imputed Data}

Questions 1 through 3 have the following responses: $1=$ Agree Strongly, $2=$ Agree, $3=$ Neither Agree nor Disagree, 4 = Disagree, $5=$ Strongly Disagree, $6=$ Can't Choose, Refused.

1. How much do you agree or disagree with the following statement: The United States should limit the import of foreign products in order to protect its national economy.

$\begin{array}{ll}\text { Mean Response } & 2.2589 \\ \text { Standard Error of Mean } & 0.0282 \\ \text { Number of Respondents } & 1,367 \\ \text { Missing Observations Imputed } & 77\end{array}$

2. For certain problems, international bodies (e.g. United Nations, European Union, World Health Organization) should have the right to enforce solutions.

Mean Response

Standard Error of Mean

0.0271

Number of Respondents

Missing Observations Imputed
1,367

112

3. How much do you agree or disagree with the following statement: The United States should follow its own interest, even if this leads to conflicts with other nations.
Mean Response
2.7509
Standard Error of Mean
0.0297
Number of Respondents
1,367
Missing Observations Imputed
67

4. Do you think the number of immigrants to the United States nowadays should be $1=$ Increased a Lot, $2=$ Increased a Little, $3=$ Remain the Same, $4=$ Reduced a Little, $5=$ Reduced a lot, $6=$ Can't

Choose, Refused

$\begin{array}{ll}\text { Mean Response } & 3.8715 \\ \text { Standard Error of Mean } & 0.0330 \\ \text { Number of Respondents } & 1,367 \\ \text { Number of Observations } & 226\end{array}$

International Interactions, Vol. 31, No. 4 (2005): pg. 273-301. DOI. This article is @ Taylor \& Francis (Routledge) and permission has been granted for this version to appear in e-Publications@Marquette. Taylor \& Francis (Routledge) does not grant permission for this article to be further copied/distributed or hosted elsewhere without the express permission from Taylor \& Francis (Routledge). 
NOT THE PUBLISHED VERSION; this is the author's final, peer-reviewed manuscript. The published version may be accessed by following the link in the citation at the bottom of the page.

Table 2. Summary Description of Demographic, Economic, Ideology, and Religiosity Variables (mean of imputed data and use of the mean)

\begin{tabular}{|c|c|c|c|c|}
\hline Variable & Description & Mean (Number) & Standard Error & MissingObservations \\
\hline Female & $\begin{array}{l}\text { Female }=1 \text {, Male } \\
=0\end{array}$ & $0.5653(772)$ & 0.0134 & 0 \\
\hline Age & Years & 44.4902 & 0.4483 & 4 \\
\hline Education & Years & 13.4205 & 0.7774 & 3 \\
\hline Union & $\begin{array}{l}\text { Member }=1 \text {, } \\
\text { Nonmember }=0\end{array}$ & $0.2002(180)$ & 0.4000 & 6 \\
\hline Social Class & $\begin{array}{l}\text { Lower Class }=1 \text {, } \\
\text { Working Class }=2 \text {, } \\
\text { Lower-Middle Class } \\
=3 \text {, Middle Class } \\
=4, \text { Upper-Middle } \\
\text { Class }=5 \text {, Upper } \\
\text { Class }=6\end{array}$ & 2.9634 & 0.0325 & 10 \\
\hline Left/Right & $\begin{array}{l}\text { Far Left }=1 \text {, Left } \\
=2 \text {, Centre }=3, \\
\text { Right }=4 \text {, Far Right } \\
=5\end{array}$ & 2.9882 & 0.0240 & 2 \\
\hline Hispanic & $\begin{array}{l}\text { Hispanic }=1, \text { Not } \\
\text { Hispanic }=0\end{array}$ & $(50)$ & & 0 \\
\hline African American & $\begin{array}{l}\text { African American }= \\
1, \text { Not African } \\
\text { American }=2\end{array}$ & $(92)$ & & 0 \\
\hline Religiosity & $\begin{array}{l}\text { Two-three times a } \\
\text { month or once a } \\
\text { week or more }=1 \text {, } \\
\text { less than two-three } \\
\text { times a month }=0\end{array}$ & 0.4001 & 0.0325 & 42 \\
\hline
\end{tabular}

International Interactions, Vol. 31, No. 4 (2005): pg. 273-301. DOI. This article is @ Taylor \& Francis (Routledge) and permission has been granted for this version to appear in e-Publications@ Marquette. Taylor \& Francis (Routledge) does not grant permission for this article to be further copied/distributed or hosted elsewhere without the express permission from Taylor \& Francis (Routledge). 


\section{Table 3. Base Model/Major Denominations (p-values in parentheses.)}

\begin{tabular}{|c|c|c|c|c|c|c|c|c|}
\hline \multirow{2}{*}{$\begin{array}{l}\text { Variable } \\
\text { Female }\end{array}$} & \multicolumn{2}{|c|}{ Imports } & \multicolumn{2}{|c|}{ Institutions } & \multicolumn{2}{|c|}{ Unilateral } & \multicolumn{2}{|c|}{ Immigration } \\
\hline & -0.0935 & -0.0762 & -0.063 & -0.0797 & 0.1246 & 0.1391 & 0.101 & 0.0976 \\
\hline & {$[0.125]$} & {$[0.213]$} & {$[0.298]$} & {$[0.193]$} & {$[0.034]$} & {$[0.020]$} & {$[0.097]$} & {$[0.112]$} \\
\hline \multirow[t]{2}{*}{ Age } & -0.004 & -0.003 & 0.0044 & 0.0036 & -0.0012 & -0.0006 & 0.0056 & 0.0051 \\
\hline & {$[0.035]$} & {$[0.137]$} & {$[0.042]$} & {$[0.109]$} & {$[0.532]$} & {$[0.766]$} & {$[0.013]$} & {$[0.028]$} \\
\hline \multirow[t]{2}{*}{ Skill Level } & 0.1135 & 0.1097 & -0.0056 & -0.0009 & 0.0937 & 0.092 & -0.047 & -0.0437 \\
\hline & {$[0.000]$} & {$[0.000]$} & {$[0.625]$} & {$[0.937]$} & {$[0.000]$} & {$[0.000]$} & {$[0.000]$} & {$[0.001]$} \\
\hline \multirow{3}{*}{$\begin{array}{l}\text { Union } \\
\text { Member }\end{array}$} & -0.3387 & -0.343 & -0.0715 & -0.0809 & -0.0782 & -0.0763 & 0.0196 & 0.0212 \\
\hline & & & & & & & & \\
\hline & {$[0.000]$} & {$[0.000]$} & {$[0.419]$} & {$[0.364]$} & {$[0.460]$} & {$[0.478]$} & {$[0.866]$} & {$[0.860]$} \\
\hline \multirow{2}{*}{$\begin{array}{l}\text { Political } \\
\text { Ideology }\end{array}$} & 0.0365 & 0.0446 & 0.1172 & 0.1043 & -0.0481 & -0.0518 & 0.0762 & 0.0644 \\
\hline & {$[0.297]$} & {$[0.218]$} & {$[0.001]$} & {$[0.003]$} & {$[0.196]$} & {$[0.166]$} & {$[0.045]$} & {$[0.091]$} \\
\hline \multirow{3}{*}{$\begin{array}{l}\text { Social } \\
\text { Class }\end{array}$} & 0.062 & 0.0654 & 0.0012 & -0.0015 & 0.0089 & 0.0156 & -0.0536 & -0.048 \\
\hline & & & & & & & & \\
\hline & {$[0.023]$} & {$[0.017]$} & {$[0.965]$} & {$[0.957]$} & {$[0.731]$} & {$[0.554]$} & {$[0.061]$} & [0.099] \\
\hline \multirow{3}{*}{$\begin{array}{l}\text { African } \\
\text { American }\end{array}$} & -0.2539 & -0.1672 & 0.2095 & 0.1678 & -0.1044 & -0.0477 & -0.1619 & -0.1989 \\
\hline & & & & & & & & \\
\hline & {$[0.051]$} & {$[0.206]$} & {$[0.117]$} & {$[0.220]$} & {$[0.382]$} & {$[0.699]$} & {$[0.193]$} & {$[0.120]$} \\
\hline \multirow[t]{2}{*}{ Hispanic } & 0.4177 & 0.4234 & -0.0787 & -0.0506 & 0.2709 & 0.2669 & -0.4916 & -0.4427 \\
\hline & {$[0.013]$} & {$[0.011]$} & {$[0.647]$} & {$[0.774]$} & {$[0.108]$} & {$[0.110]$} & {$[0.006]$} & {$[0.013]$} \\
\hline \multirow[t]{2}{*}{ Jewish } & & -0.0379 & & 0.0648 & & -0.3909 & & -0.2673 \\
\hline & & {$[0.868]$} & & {$[0.768]$} & & {$[0.068]$} & & {$[0.234]$} \\
\hline \multirow[t]{2}{*}{ Catholic } & & -0.2599 & & 0.0604 & & -0.1401 & & -0.0469 \\
\hline & & {$[0.011]$} & & {$[0.545]$} & & {$[0.174]$} & & {$[0.637]$} \\
\hline \multirow[t]{2}{*}{ Baptist } & & -0.3295 & & 0.1383 & & -0.2133 & & 0.065 \\
\hline & & {$[0.001]$} & & {$[0.180]$} & & {$[0.038]$} & & {$[0.548]$} \\
\hline \multirow[t]{2}{*}{ Methodist } & & -0.3311 & & 0.0331 & & -0.0943 & & 0.2271 \\
\hline & & {$[0.011]$} & & {$[0.797]$} & & {$[0.458]$} & & {$[0.104]$} \\
\hline \multirow[t]{2}{*}{ Lutheran } & & -0.1533 & & 0.3047 & & -0.131 & & 0.0519 \\
\hline & & {$[0.287]$} & & {$[0.026]$} & & {$[0.331]$} & & {$[0.719]$} \\
\hline \multirow{2}{*}{$\begin{array}{l}\text { Episcopalia } \\
\mathrm{n}\end{array}$} & & -0.0353 & & 0.0156 & & -0.1224 & & 0.0583 \\
\hline & & {$[0.872]$} & & {$[0.945]$} & & {$[0.594]$} & & {$[0.789]$} \\
\hline
\end{tabular}

International Interactions, Vol. 31, No. 4 (2005): pg. 273-301. DOI. This article is @ Taylor \& Francis (Routledge) and permission has been granted for this version to appear in e-Publications@Marquette. Taylor \& Francis (Routledge) does not grant permission for this article to be further copied/distributed or hosted elsewhere without the express permission from Taylor \& Francis (Routledge). 
NOT THE PUBLISHED VERSION; this is the author's final, peer-reviewed manuscript. The published version may be accessed by following the link in the citation at the bottom of the page.

$\begin{array}{lllll}\text { Presbyteria } & -0.3965 & -0.0215 & -0.0338 & 0.0791 \\ \mathrm{n} & {[0.026]} & {[0.904]} & {[0.845]} & {[0.683]} \\ \text { Other } & -0.2305 & 0.3102 & -0.0273 & 0.1407 \\ \text { Protestant } & {[0.074]} & {[0.012]} & & {[0.266]} \\ & 0.0838 & -0.2107 & {[0.825]} & -0.0932 \\ \text { Other } & {[0.597]} & {[0.184]} & 0.1262 & {[0.579]} \\ \text { Christian } & -0.0216 & 0.06 & {[0.419]} & -0.0345 \\ & {[0.740]} & {[0.369]} & -0.0553 & {[0.613]}\end{array}$

International Interactions, Vol. 31, No. 4 (2005): pg. 273-301. DOI. This article is @ Taylor \& Francis (Routledge) and permission has been granted for this version to appear in e-Publications@ Marquette. Taylor \& Francis (Routledge) does not grant permission for this article to be further copied/distributed or hosted elsewhere without the express permission from Taylor \& Francis (Routledge). 


\section{Table 4. NORC Classification System / Augmented NORC Classification System (p-values in parentheses.)}

\begin{tabular}{|c|c|c|c|c|c|c|c|c|}
\hline \multirow[b]{2}{*}{ Female } & \multicolumn{2}{|l|}{ Imports } & \multicolumn{2}{|c|}{ Institutions } & \multicolumn{2}{|c|}{ Unilateral } & \multicolumn{2}{|c|}{ Immigration } \\
\hline & -0.0794 & -0.0863 & -0.0829 & -0.0829 & 0.1412 & 0.1365 & 0.0965 & 0.1018 \\
\hline & {$[0.194]$} & {$[0.158]$} & {$[0.176]$} & {$[0.177]$} & {$[0.018]$} & {$[0.022]$} & {$[0.116]$} & {$[0.098]$} \\
\hline \multirow[t]{2}{*}{ Age } & -0.0033 & -0.0035 & 0.0034 & 0.0034 & -0.0005 & -0.0005 & 0.0053 & 0.0052 \\
\hline & {$[0.102]$} & {$[0.090]$} & {$[0.128]$} & {$[0.122]$} & {$[0.792]$} & {$[0.810]$} & {$[0.024]$} & {$[0.027]$} \\
\hline \multirow[t]{2}{*}{ Skill Level } & 0.1106 & 0.1104 & -0.0004 & -0.0008 & 0.0918 & 0.0928 & -0.0439 & -0.045 \\
\hline & {$[0.000]$} & {$[0.000]$} & {$[0.970]$} & {$[0.945]$} & {$[0.000]$} & {$[0.000]$} & {$[0.001]$} & {$[0.001]$} \\
\hline \multirow{3}{*}{$\begin{array}{l}\text { Union } \\
\text { Member }\end{array}$} & -0.3393 & -0.3408 & -0.0774 & -0.0814 & -0.0763 & -0.0802 & 0.0223 & 0.0273 \\
\hline & & & & & & & & \\
\hline & {$[0.000]$} & {$[0.000]$} & {$[0.385]$} & {$[0.360]$} & {$[0.477]$} & {$[0.458]$} & {$[0.852]$} & {$[0.823]$} \\
\hline \multirow{3}{*}{$\begin{array}{l}\text { Political } \\
\text { Ideology }\end{array}$} & 0.0465 & 0.044 & 0.1046 & 0.1026 & -0.0487 & -0.0542 & 0.0632 & 0.0693 \\
\hline & & & & & & & & \\
\hline & {$[0.198]$} & {$[0.224]$} & {$[0.003]$} & {$[0.004]$} & {$[0.193]$} & {$[0.152]$} & {$[0.098]$} & {$[0.072]$} \\
\hline \multirow{3}{*}{$\begin{array}{l}\text { Social } \\
\text { Class }\end{array}$} & 0.0667 & 0.0628 & -0.0011 & -0.0031 & 0.0167 & 0.0126 & -0.0496 & -0.0444 \\
\hline & & & & & & & & \\
\hline & {$[0.014]$} & {$[0.022]$} & {$[0.970]$} & {$[0.913]$} & {$[0.526]$} & {$[0.634]$} & {$[0.085]$} & {$[0.124]$} \\
\hline African & -0.5237 & -0.3437 & 0.1274 & 0.0836 & -0.1446 & 0.0436 & -0.1668 & -0.3171 \\
\hline \multicolumn{9}{|l|}{ American } \\
\hline Baptist & {$[0.003]$} & {$[0.044]$} & {$[0.516]$} & {$[0.660]$} & {$[0.406]$} & {$[0.796]$} & {$[0.356]$} & {$[0.081]$} \\
\hline African & -0.2166 & -0.1799 & 0.4066 & 0.4055 & -0.2538 & -0.2498 & -0.0963 & -0.1131 \\
\hline \multicolumn{9}{|l|}{ American } \\
\hline Il Others & {$[0.277]$} & {$[0.367]$} & {$[0.022]$} & {$[0.023]$} & {$[0.148]$} & {$[0.154]$} & {$[0.610]$} & {$[0.547]$} \\
\hline \multirow[t]{2}{*}{ Hispanic } & 0.421 & 0.4295 & -0.0434 & -0.046 & 0.2587 & 0.2611 & -0.4381 & -0.4397 \\
\hline & {$[0.012]$} & {$[0.010]$} & {$[0.806]$} & {$[0.794]$} & {$[0.121]$} & {$[0.118]$} & {$[0.014]$} & {$[0.014]$} \\
\hline \multirow[t]{2}{*}{ Jewish } & -0.0314 & 0.0326 & 0.0683 & 0.0634 & -0.41 & -0.3765 & -0.2713 & -0.2921 \\
\hline & {$[0.891]$} & {$[0.887]$} & {$[0.755]$} & {$[0.772]$} & {$[0.056]$} & {$[0.077]$} & {$[0.222]$} & {$[0.191]$} \\
\hline \multirow[t]{2}{*}{ Catholic } & -0.256 & -0.1958 & 0.0603 & 0.053 & -0.158 & -0.1245 & -0.0495 & -0.0682 \\
\hline & {$[0.012]$} & {$[0.049]$} & {$[0.538]$} & {$[0.586]$} & {$[0.117]$} & {$[0.214]$} & {$[0.617]$} & {$[0.483]$} \\
\hline \multirow{3}{*}{$\begin{array}{l}\text { Liberal } \\
\text { Protestant }\end{array}$} & -0.258 & -0.0062 & 0.0499 & 0.1404 & -0.0841 & 0.0194 & 0.1424 & 0.0312 \\
\hline & & & & & & & & \\
\hline & {$[0.028]$} & {$[0.968]$} & {$[0.669]$} & {$[0.363]$} & {$[0.464]$} & {$[0.904]$} & {$[0.237]$} & {$[0.849]$} \\
\hline \multirow{3}{*}{$\begin{array}{l}\text { United } \\
\text { Methodist }\end{array}$} & & -0.3014 & & -0.0171 & & -0.0827 & & 0.1903 \\
\hline & & & & & & & & \\
\hline & & {$[0.027]$} & & {$[0.900]$} & & {$[0.532]$} & & {$[0.172]$} \\
\hline
\end{tabular}

International Interactions, Vol. 31, No. 4 (2005): pg. 273-301. DOI. This article is @ Taylor \& Francis (Routledge) and permission has been granted for this version to appear in e-Publications@Marquette. Taylor \& Francis (Routledge) does not grant permission for this article to be further copied/distributed or hosted elsewhere without the express permission from Taylor \& Francis (Routledge). 
NOT THE PUBLISHED VERSION; this is the author's final, peer-reviewed manuscript. The published version may be accessed by following the link in the citation at the bottom of the page.

\begin{tabular}{|c|c|c|c|c|c|c|c|c|}
\hline \multirow{3}{*}{$\begin{array}{l}\text { Moderate } \\
\text { Protestant }\end{array}$} & -0.087 & -0.026 & 0.2046 & 0.1974 & -0.1044 & -0.0716 & -0.1033 & -0.1219 \\
\hline & & & & & & & & \\
\hline & {$[0.560]$} & {$[0.861]$} & {$[0.161]$} & {$[0.182]$} & {$[0.464]$} & {$[0.616]$} & [0.494] & {$[0.414]$} \\
\hline \multirow{2}{*}{$\begin{array}{l}\text { Conservati } \\
\mathrm{e} \\
\text { Protestant }\end{array}$} & $v-0.3481$ & -0.2237 & 0.1904 & 0.2306 & -0.2845 & -0.1378 & 0.1315 & -0.0349 \\
\hline & {$[0.001]$} & {$[0.046]$} & {$[0.070]$} & {$[0.045]$} & {$[0.005]$} & {$[0.230]$} & {$[0.246]$} & {$[0.777]$} \\
\hline \multicolumn{2}{|l|}{ Southern } & -0.2905 & & 0.0811 & & -0.3876 & & 0.33 \\
\hline \multicolumn{9}{|l|}{ Baptist } \\
\hline & & {$[0.018]$} & & {$[0.519]$} & & {$[0.001]$} & & {$[0.014]$} \\
\hline \multirow{3}{*}{$\begin{array}{l}\text { Other } \\
\text { Protestant }\end{array}$} & -0.226 & -0.1633 & 0.3052 & 0.2969 & -0.043 & -0.0065 & 0.1369 & 0.1168 \\
\hline & & & & & & & & \\
\hline & [0.079] & [0.195] & {$[0.011]$} & {$[0.014]$} & {$[0.727]$} & {$[0.957]$} & {$[0.276]$} & {$[0.346]$} \\
\hline \multirow{3}{*}{$\begin{array}{l}\text { Other } \\
\text { Christian }\end{array}$} & 0.0871 & 0.1463 & -0.2064 & -0.2132 & 0.107 & 0.1381 & -0.0947 & -0.1112 \\
\hline & & & & & & & & \\
\hline & {$[0.581]$} & [0.349] & {$[0.197]$} & {$[0.174]$} & {$[0.492]$} & {$[0.369]$} & {$[0.566]$} & {$[0.503]$} \\
\hline \multirow[t]{2}{*}{ Religiosity } & -0.0089 & -0.0175 & 0.0621 & 0.0677 & -0.0465 & -0.054 & -0.0457 & -0.0416 \\
\hline & {$[0.891]$} & [0.789] & {$[0.360]$} & {$[0.317]$} & {$[0.457]$} & {$[0.386]$} & {$[0.512]$} & {$[0.548]$} \\
\hline
\end{tabular}

International Interactions, Vol. 31, No. 4 (2005): pg. 273-301. DOI. This article is @ Taylor \& Francis (Routledge) and permission has been granted for this version to appear in e-Publications@ Marquette. Taylor \& Francis (Routledge) does not grant permission for this article to be further copied/distributed or hosted elsewhere without the express permission from Taylor \& Francis (Routledge). 
NOT THE PUBLISHED VERSION; this is the author's final, peer-reviewed manuscript. The published version may be accessed by following the link in the citation at the bottom of the page.

\section{Table 5. RM Classification System / Augmented RM Classification System (p-values in parentheses.)}

\begin{tabular}{|c|c|c|c|c|c|c|c|c|}
\hline \multirow[b]{2}{*}{ Female } & \multicolumn{2}{|c|}{ Imports } & \multicolumn{2}{|c|}{ Institutions } & \multicolumn{2}{|c|}{ Unilateral } & \multicolumn{2}{|c|}{ Immigration } \\
\hline & -0.0789 & -0.0804 & -0.0809 & -0.0826 & 0.139 & 0.1379 & 0.0981 & 0.1015 \\
\hline & [0.197] & [0.189] & {$[0.187]$} & {$[0.178]$} & {$[0.020]$} & {$[0.021]$} & {$[0.110]$} & {$[0.100]$} \\
\hline \multirow[t]{2}{*}{ Age } & -0.0032 & -0.0033 & 0.0034 & 0.0035 & -0.0004 & -0.0005 & 0.0054 & 0.0052 \\
\hline & {$[0.114]$} & {$[0.113]$} & {$[0.137]$} & {$[0.118]$} & {$[0.832]$} & {$[0.803]$} & {$[0.024]$} & {$[0.025]$} \\
\hline \multirow[t]{2}{*}{ Skill Level } & 0.1105 & 0.1089 & -0.0013 & -0.0019 & 0.0918 & 0.0913 & -0.0426 & -0.0425 \\
\hline & {$[0.000]$} & {$[0.000]$} & {$[0.912]$} & {$[0.871]$} & {$[0.000]$} & {$[0.000]$} & {$[0.002]$} & {$[0.002]$} \\
\hline \multirow{3}{*}{$\begin{array}{l}\text { Union } \\
\text { Member }\end{array}$} & -0.3428 & -0.3537 & -0.071 & -0.0805 & -0.0852 & -0.0889 & 0.0143 & 0.024 \\
\hline & & & & & & & & \\
\hline & {$[0.000]$} & {$[0.000]$} & {$[0.432]$} & {$[0.375]$} & {$[0.435]$} & {$[0.418]$} & {$[0.904]$} & {$[0.841]$} \\
\hline \multirow{2}{*}{$\begin{array}{l}\text { Political } \\
\text { Ideology }\end{array}$} & 0.0456 & 0.0457 & 0.099 & 0.0982 & -0.0465 & -0.0467 & 0.0663 & 0.0674 \\
\hline & {$[0.211]$} & {$[0.212]$} & {$[0.005]$} & {$[0.005]$} & {$[0.212]$} & {$[0.208]$} & {$[0.080]$} & {$[0.077]$} \\
\hline \multirow{3}{*}{$\begin{array}{l}\text { Social } \\
\text { Class }\end{array}$} & 0.0632 & 0.0612 & -0.0015 & -0.0027 & 0.0161 & 0.0144 & -0.0481 & -0.0464 \\
\hline & & & & & & & & \\
\hline & {$[0.021]$} & {$[0.026]$} & {$[0.958]$} & {$[0.922]$} & {$[0.542]$} & {$[0.588]$} & {$[0.098]$} & {$[0.111]$} \\
\hline \multirow{3}{*}{$\begin{array}{l}\text { Black } \\
\text { Protestant }\end{array}$} & -0.4985 & -0.503 & 0.1959 & 0.1972 & -0.1117 & -0.1127 & -0.1341 & -0.1361 \\
\hline & & & & & & & & \\
\hline & {$[0.003]$} & {$[0.003]$} & {$[0.260]$} & {$[0.258]$} & {$[0.486]$} & {$[0.483]$} & {$[0.425]$} & {$[0.418]$} \\
\hline \multirow[t]{2}{*}{ Hispanic } & 0.4245 & 0.4183 & -0.0651 & -0.0669 & 0.2715 & 0.2653 & -0.4309 & -0.4282 \\
\hline & {$[0.011]$} & {$[0.012]$} & {$[0.711]$} & {$[0.705]$} & {$[0.104]$} & {$[0.112]$} & {$[0.016]$} & {$[0.016]$} \\
\hline \multirow[t]{2}{*}{ Jewish } & -0.0286 & -0.0243 & 0.0519 & 0.0526 & -0.3818 & -0.3789 & -0.2774 & -0.2789 \\
\hline & {$[0.901]$} & [0.916] & {$[0.813]$} & {$[0.811]$} & {$[0.074]$} & {$[0.077]$} & {$[0.216]$} & {$[0.215]$} \\
\hline \multirow[t]{2}{*}{ Catholic } & -0.2543 & -0.2548 & 0.0474 & 0.049 & -0.13 & -0.1289 & -0.0547 & -0.0572 \\
\hline & {$[0.013]$} & {$[0.013]$} & {$[0.635]$} & {$[0.623]$} & {$[0.206]$} & {$[0.211]$} & {$[0.581]$} & {$[0.563]$} \\
\hline \multirow{3}{*}{$\begin{array}{l}\text { Liberal } \\
\text { Protestant }\end{array}$} & -0.2418 & -0.2405 & -0.016 & -0.0162 & -0.0622 & -0.0598 & 0.0586 & 0.0577 \\
\hline & & & & & & & & \\
\hline & {$[0.102]$} & {$[0.104]$} & {$[0.915]$} & {$[0.913]$} & {$[0.677]$} & [0.689] & {$[0.707]$} & {$[0.712]$} \\
\hline \multirow{3}{*}{$\begin{array}{l}\text { Moderate } \\
\text { Protestant }\end{array}$} & -0.2249 & -0.1263 & 0.1354 & 0.2624 & -0.1187 & -0.1022 & 0.1104 & 0.0338 \\
\hline & & & & & & & & \\
\hline & [0.029] & {$[0.382]$} & {$[0.176]$} & {$[0.057]$} & {$[0.250]$} & {$[0.450]$} & {$[0.315]$} & {$[0.815]$} \\
\hline \multirow{4}{*}{$\begin{array}{l}\text { Non- } \\
\text { Southern } \\
\text { Methodists }\end{array}$} & & -0.3187 & & 0.0193 & & 0.0715 & & 0.0502 \\
\hline & & & & & & & & \\
\hline & & & & & & & & \\
\hline & & {$[0.048]$} & & {$[0.906]$} & & {$[0.652]$} & & {$[0.767]$} \\
\hline
\end{tabular}

International Interactions, Vol. 31, No. 4 (2005): pg. 273-301. DOI. This article is @ Taylor \& Francis (Routledge) and permission has been granted for this version to appear in e-Publications@Marquette. Taylor \& Francis (Routledge) does not grant permission for this article to be further copied/distributed or hosted elsewhere without the express permission from Taylor \& Francis (Routledge). 
NOT THE PUBLISHED VERSION; this is the author's final, peer-reviewed manuscript. The published version may be accessed by following the link in the citation at the bottom of the page.

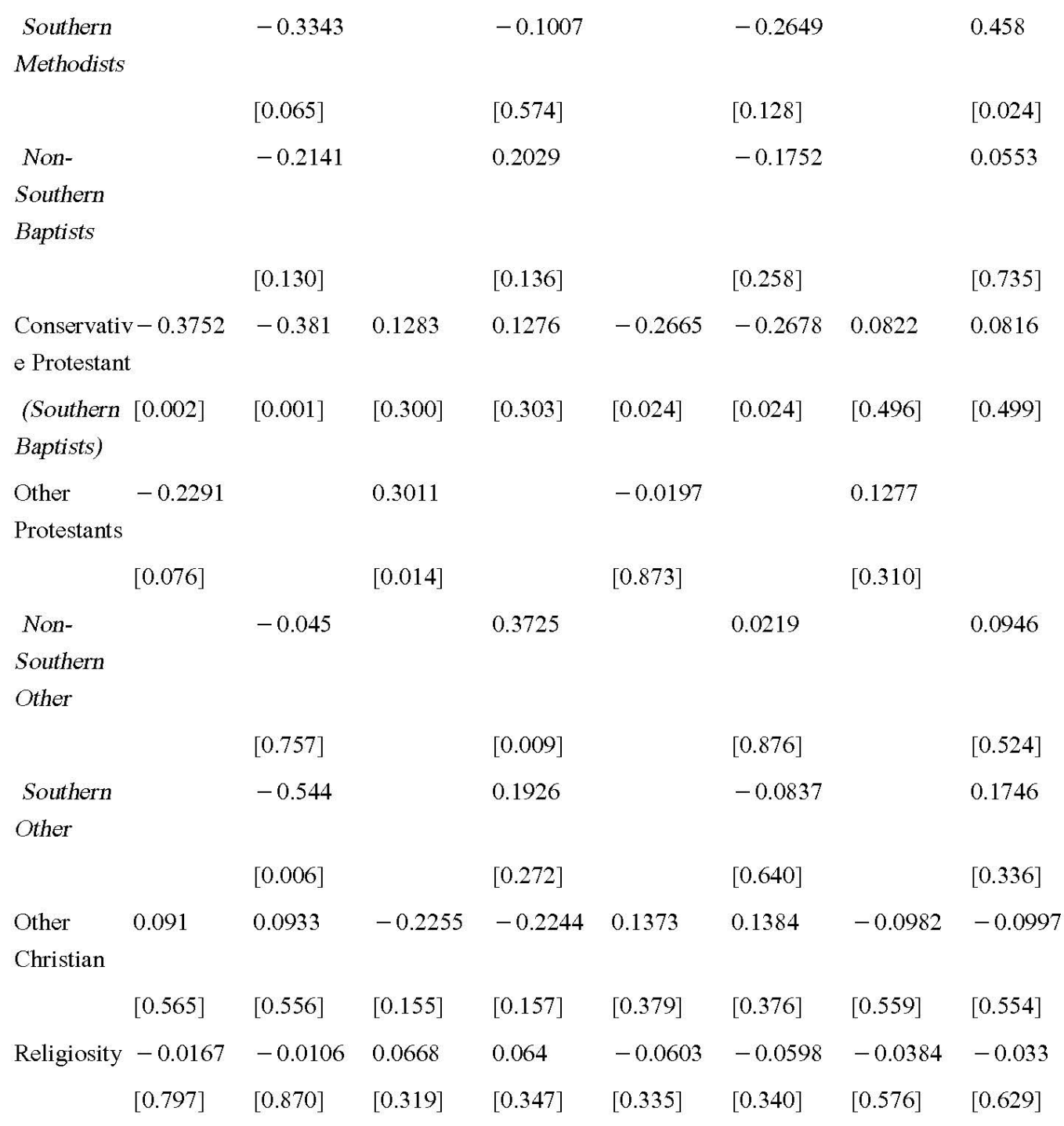

International Interactions, Vol. 31, No. 4 (2005): pg. 273-301. DOI. This article is @ Taylor \& Francis (Routledge) and permission has been granted for this version to appear in e-Publications@Marquette. Taylor \& Francis (Routledge) does not grant permission for this article to be further copied/distributed or hosted elsewhere without the express permission from Taylor \& Francis (Routledge). 
NOT THE PUBLISHED VERSION; this is the author's final, peer-reviewed manuscript. The published version may be accessed by following the link in the citation at the bottom of the page.

Figure 1. Distribution among Major Denominations.

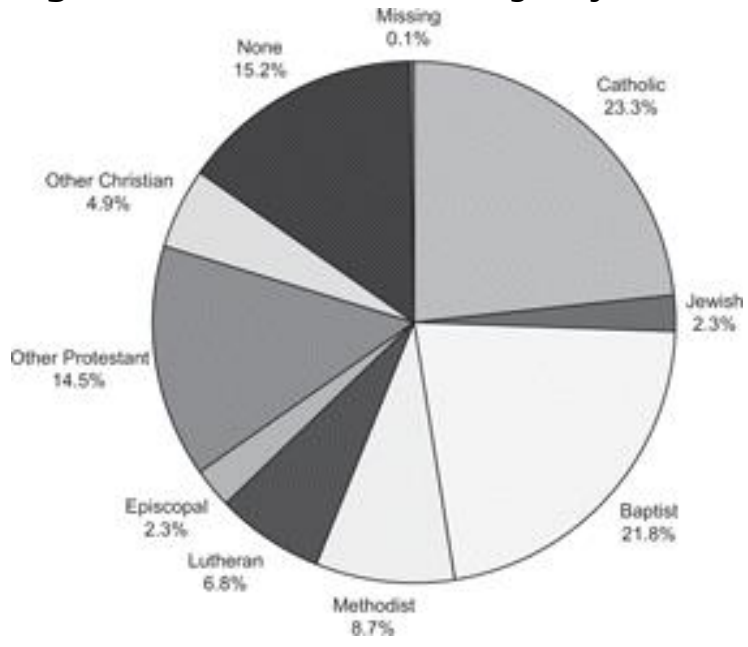

Figure 2. U. S. Should Restrict Imports.

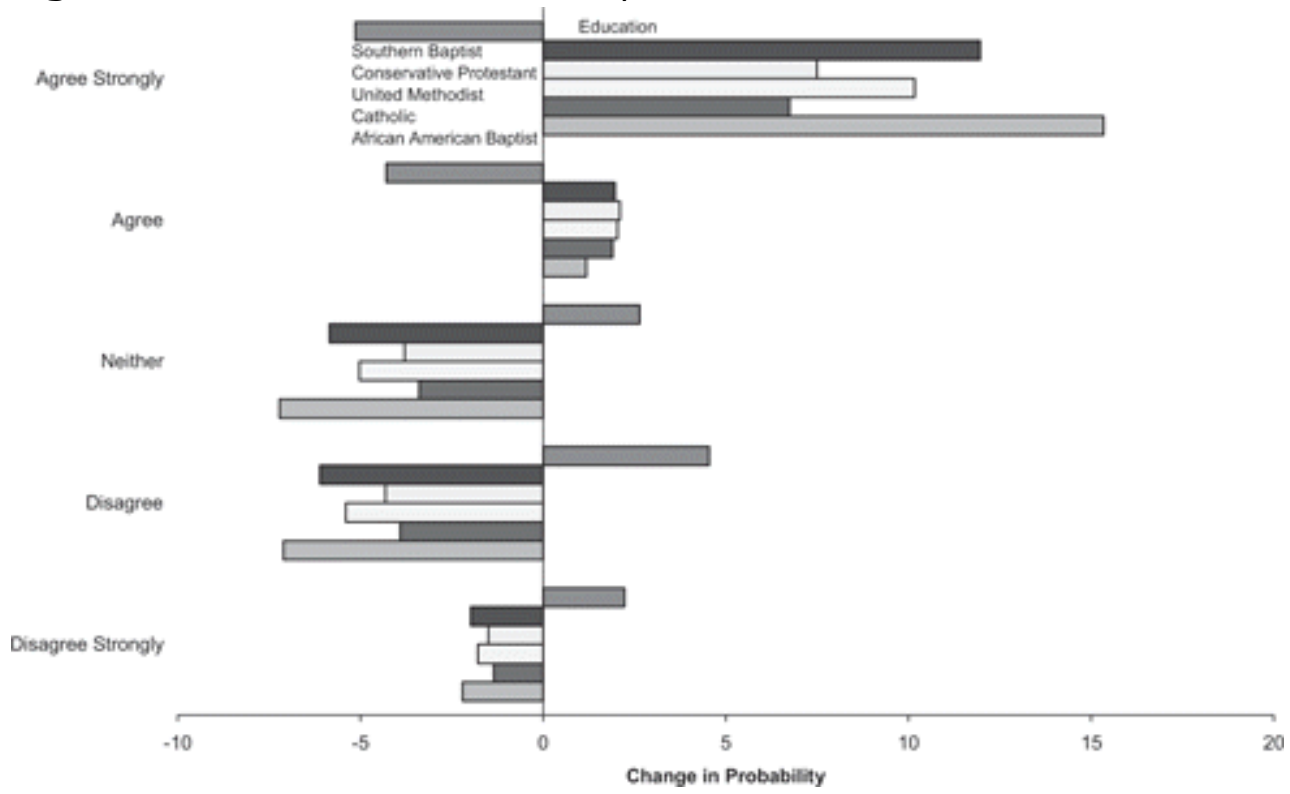

International Interactions, Vol. 31, No. 4 (2005): pg. 273-301. DOI. This article is @ Taylor \& Francis (Routledge) and permission has been granted for this version to appear in e-Publications@ Marquette. Taylor \& Francis (Routledge) does not grant permission for this article to be further copied/distributed or hosted elsewhere without the express permission from Taylor \& Francis (Routledge). 
NOT THE PUBLISHED VERSION; this is the author's final, peer-reviewed manuscript. The published version may be accessed by following the link in the citation at the bottom of the page.

Figure 3. Institution Rights.

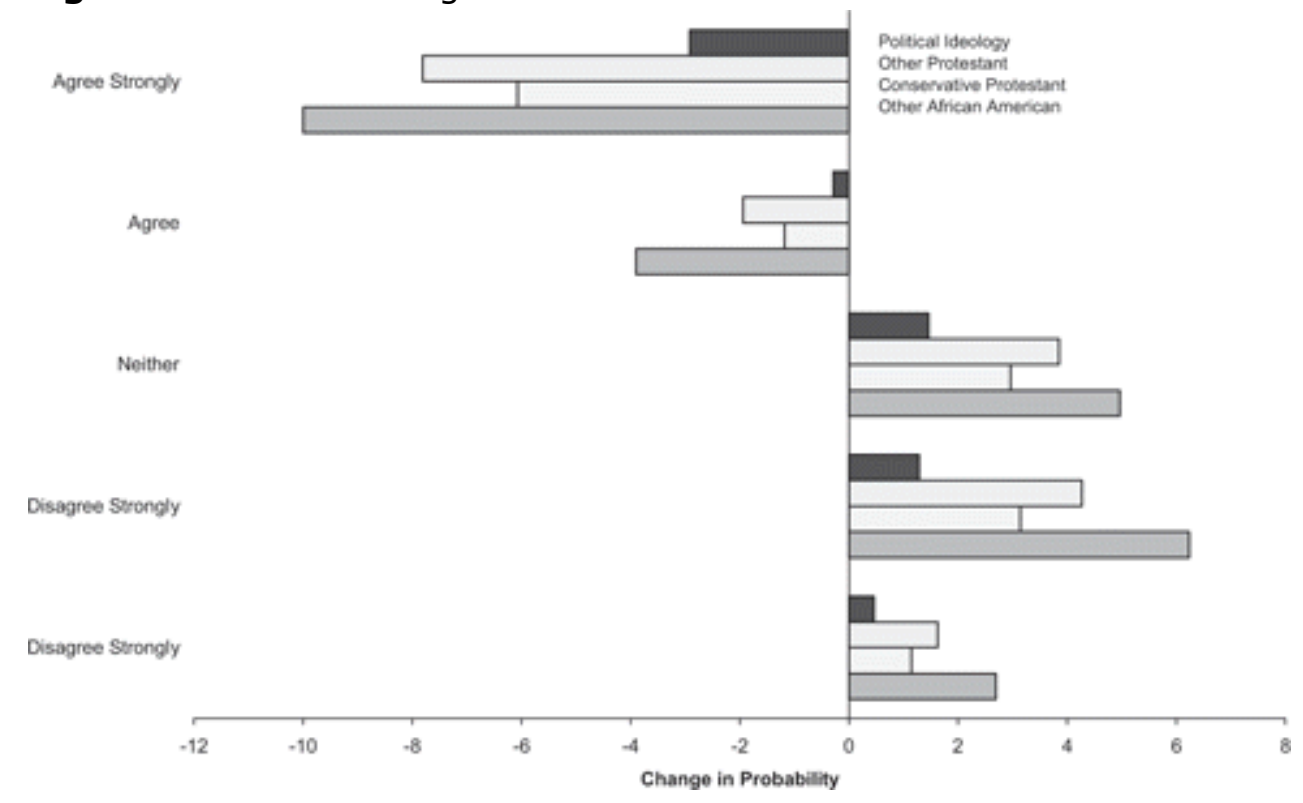

Figure 4. Unilateral Actions.

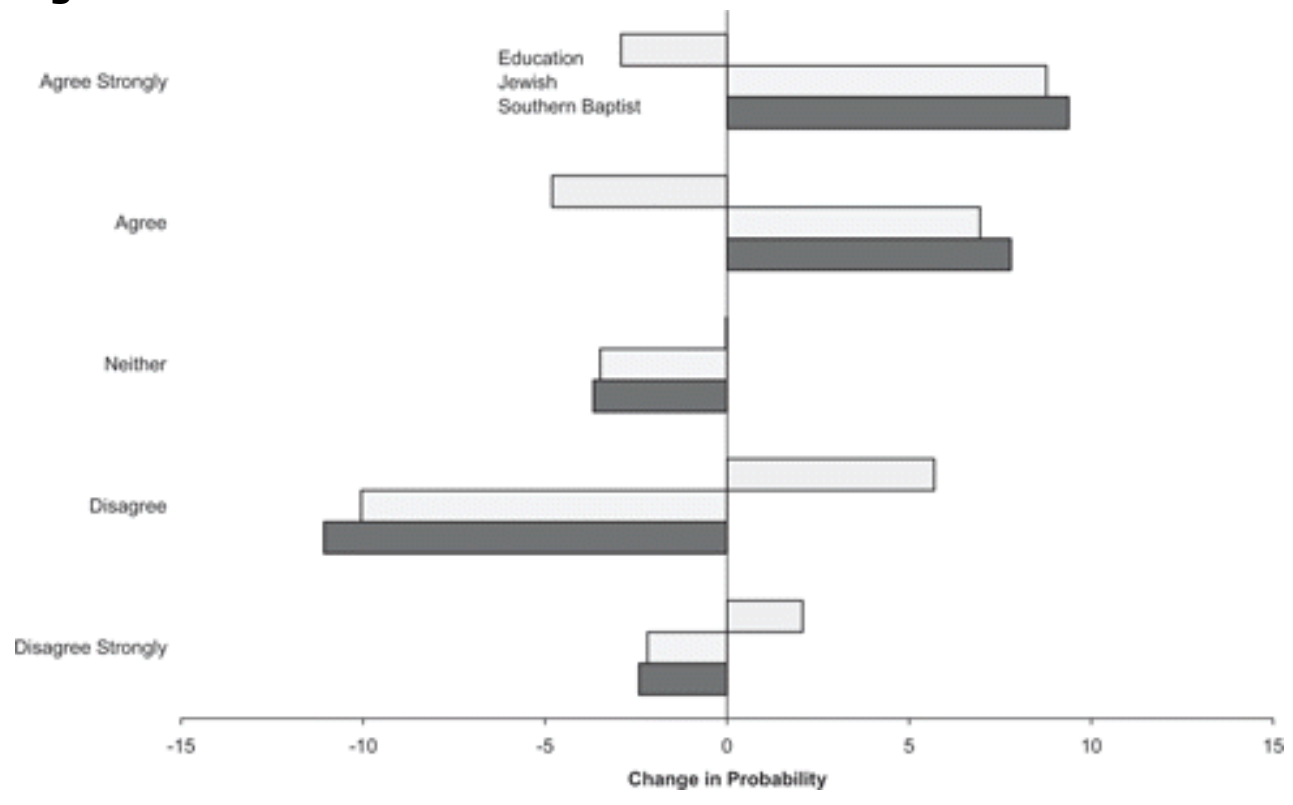

International Interactions, Vol. 31, No. 4 (2005): pg. 273-301. DOI. This article is @ Taylor \& Francis (Routledge) and permission has been granted for this version to appear in e-Publications@ Marquette. Taylor \& Francis (Routledge) does not grant permission for this article to be further copied/distributed or hosted elsewhere without the express permission from Taylor \& Francis (Routledge). 
NOT THE PUBLISHED VERSION; this is the author's final, peer-reviewed manuscript. The published version may be accessed by following the link in the citation at the bottom of the page.

Figure 5. Increase Immigration.

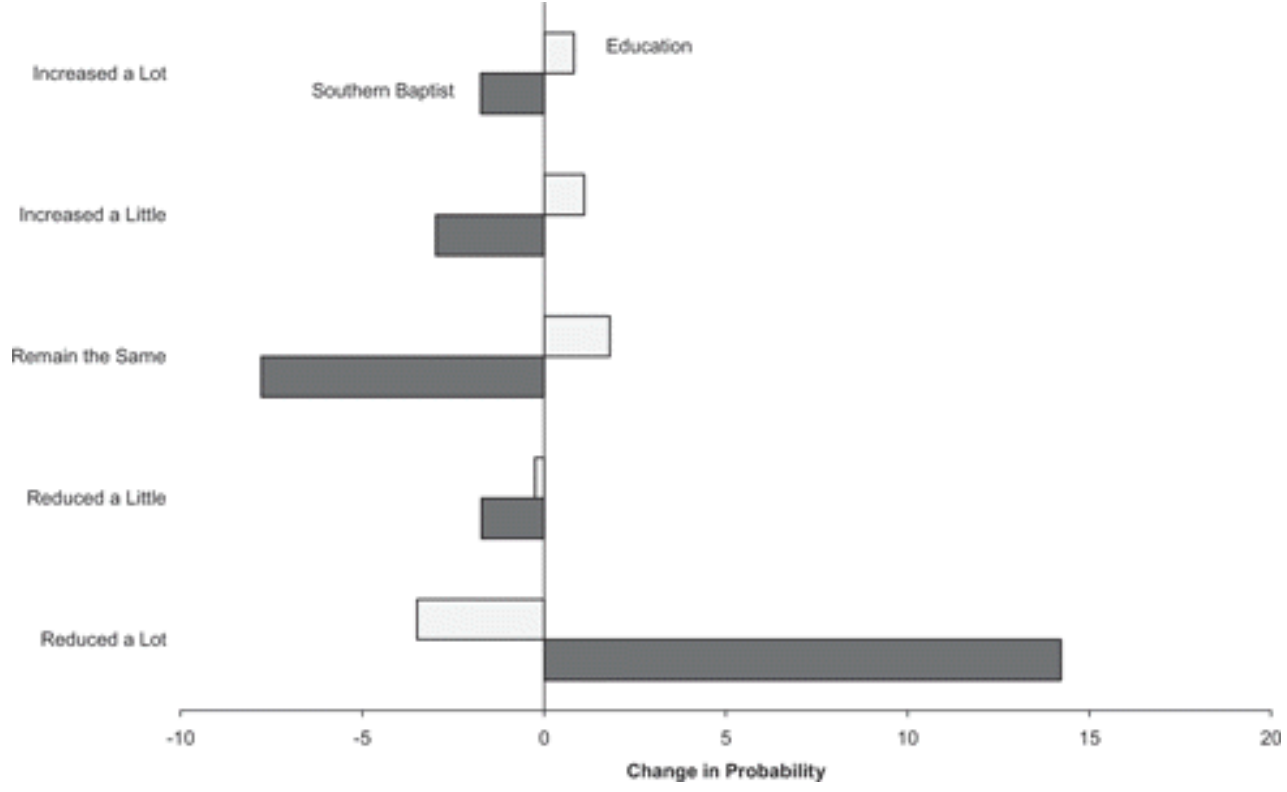

International Interactions, Vol. 31, No. 4 (2005): pg. 273-301. DOI. This article is (C) Taylor \& Francis (Routledge) and permission has been granted for this version to appear in e-Publications@ Marquette. Taylor \& Francis (Routledge) does not grant permission for this article to be further copied/distributed or hosted elsewhere without the express permission from Taylor \& Francis (Routledge). 